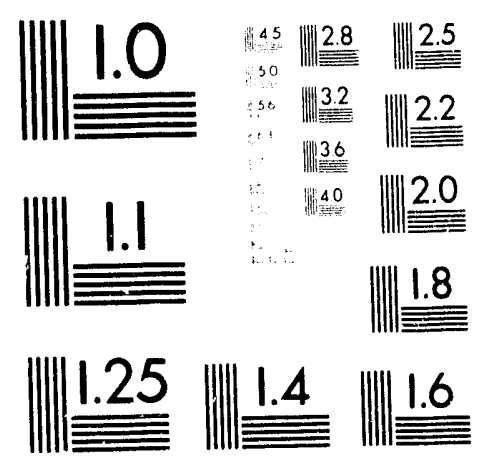



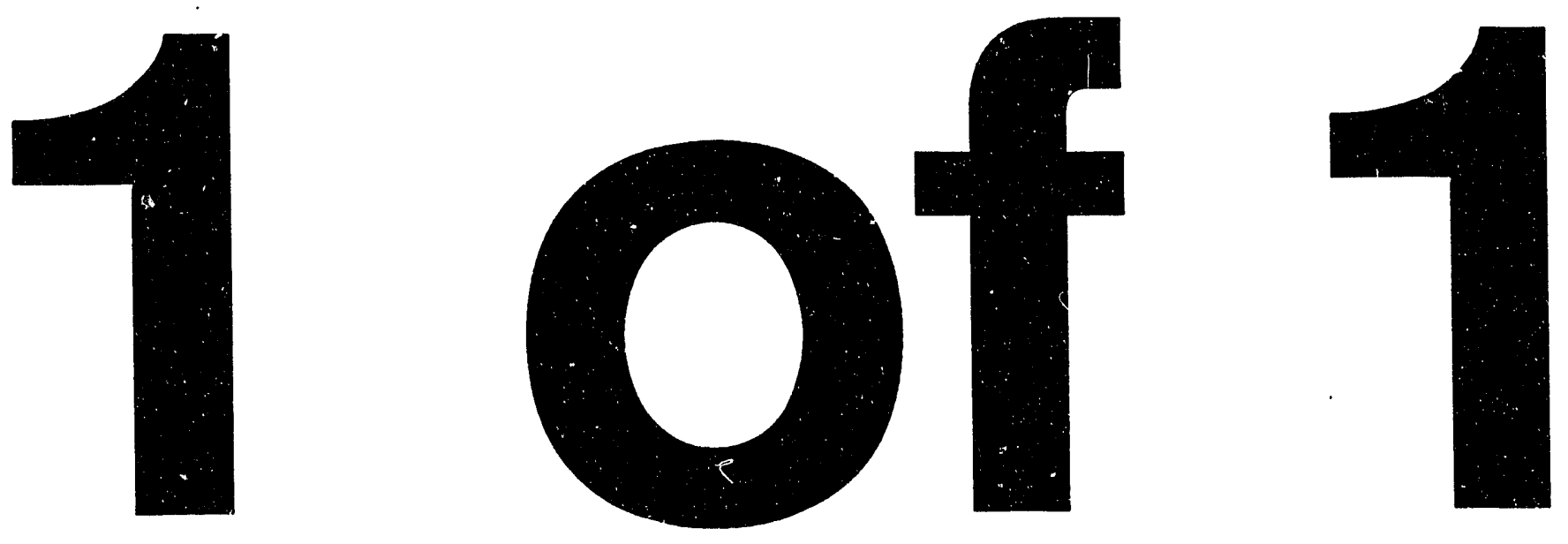


\title{
AIR-NITRIC ACID DESTRUCTIVE OXIDATION OF ORGANIC WASTES (U)
}

by

\author{
J. R. Smith \\ Westinghouse Savannah River Company \\ Savannah River Site \\ Aiken, South Carolina 29808
}

\author{
A docliment prepared for: \\ American Chemical Society "Emerging Technologies in Hazardous Waste Management V" \\ at Atlanta, GA \\ from $09 / 27 / 93$ thru $09 / 29 / 93$
}

DOE Contract No. DE-AC09-89SR18035

This paper was prepared in connection with work done under the above contract number with the U. S. Department of Energy. By acceptance of this paper, the publisher and/or recipient acknowledges the U. S. Government's right to retain a nonexclusive, royalty-free license in and to any copyright covering this paper, along with the right to reproduce and to authorize others to reproduce all or part of the copyrighted paper. 


\section{DISCLAIMER}

This report was prepared as an account of work sponsored by an agency of the United States Government. Neither the United States Government nor any agency thereof, nor any of their employees, makes any vadranty, express or implied, or assumes any legal liability or responsibility for the accuracy, completeness, or usefulness of any information, apparatus, product, or process disclosed, or represents that its use would not infringe privately owned rights. Reference herein to any specific cornmercial product, process, or service by trade name, trademark, manufacturer, or otherwise does not necessarily constitute or imply its endorsement, recommendation, or favoring by the United States Government or any agency thereof. The views and opinions of authors expressed herein do not necessarily state or reflect those of the United States Government or any agency thereof.

This report has been reproduced directly from the best available copy.

Available to DOE and DOE contractors from the Office of Scientific and Technical Information, P. O. Box 62, Oak Ridge, TN 37831; prices available from (615) $576-8401$.

Available to the public from the National Technical Information Service, U. S. Department of Commerce, 5285 Port Royal Rd., Springfield, VA 22161 
WS'RC-MS-93-169

$\mathrm{Pg} 1$ of 8

\title{
AIR-NITRIC ACID DESTRUCTIVE OXIDATION OF ORGANIC WASTES
}

\author{
James R. Smith \\ Savannah River Technology Center \\ Westinghouse Savannah River Company, Aiken, SC 29802.
}

\begin{abstract}
Many organic materials have been completely oxidized to $\mathrm{CO}_{2}, \mathrm{CO}$, and inorganic acids in a $0.1 \mathrm{M} \mathrm{HNO}_{3} / 14.8 \mathrm{M} \mathrm{H}_{3} \mathrm{PO}_{4}$ solution with air sparging. Addition of $0.001 \mathrm{M} \mathrm{Pd}^{+2}$ reduces the $\mathrm{CO}$ to near $1 \%$ of the released carbon gases. To accomplish complete oxidation the solution temperature must be maintained above $130-150^{\circ} \mathrm{C}$. Organic materials quantitatively destroyed include neoprene, cellulose, EDTA, TBP, tartaric acid, and nitromethane. The oxidation is usually complete in a few hours for soluble organic materials. The oxidation rate for non-aliphatic organic solids is moderately fast and surface area dependent. The rate for aliphatic organic compounds (polyethylene, PVC, and n-dodecane) is relatively very slow. This is due to the large energy required to abstract a hydrogen atom from these compounds, $99 \mathrm{kcal} / \mathrm{mole}$. The combination of $\mathrm{NO}_{2}$. and $\mathrm{H} \cdot$ to produce $\mathrm{HNO}_{2}$ releases only $88 \mathrm{kcal} / \mathrm{mole}$. Under conditions of high $\mathrm{NO}_{2} \cdot$ concentration it should be possible to oxidize these aliphatic compounds.
\end{abstract}

The development of a $g$ neral process for the destructive oxidation of pure organic compounds could have many applications for environmental cleanup. A liquid phase oxidation process shouldn't produce any ash making the system more environmentally contained. A simple process that uses oxygen from air or another readily available cheap oxidant as the net oxidant would be relatively inexpensive per unit of waste consumed. This work represents studies into development of such a process. Nitric acid is used as a catalyst and oxidant since it can be regenerated by air in an acid recovery system and to some extent in the reaction solution.

Liquid phase oxidation of organic molecules should be easier than gas phase oxidation at a given temperature ${ }^{1}$. This is due to the ability to produce high concentrations of the reactants and to the lessening of termination since radicals have a harder time diffusing to the walls. Direct oxidation of most organic compounds by $\mathrm{HNO}_{3}$, nitric acid, is energetically favorable but very slow due to its inability to break the carbon-hydrogen bond ${ }^{1,2}$. The following heats of reaction, $\Delta \mathrm{H}$, values (in $\mathrm{kcal} / \mathrm{mole}$ ) are calculated, or approximated, using Table 1.

$$
\begin{array}{ll}
\mathrm{RCH}_{3}+\mathrm{HNO}_{3} \rightarrow \mathrm{RCH}_{2} \mathrm{OH}+\mathrm{HNO}_{2} & \Delta \mathrm{H} \approx-25 \\
\mathrm{RCH}_{3}+\mathrm{HNO}_{3} \longrightarrow \mathrm{RCH}_{2} \cdot \mathrm{H}_{2} \mathrm{O}+\mathrm{NO}_{2} \cdot & \Delta \mathrm{H} \approx 35 \\
\mathrm{RCH}_{3}+\mathrm{HNO}_{2} \rightarrow \mathrm{RCH}_{2} \cdot+\mathrm{H}_{2} \mathrm{O}+\mathrm{NO} \cdot & \Delta \mathrm{H} \approx 28
\end{array}
$$


Table 1. Heats of Formation for Molecules and Radicals at $25^{\circ} \mathrm{C} .^{1,2}$.

\begin{tabular}{|c|c|c|c|}
\hline Compound & $\Delta \mathrm{H}_{\text {form }}(\mathrm{kcal} / \mathrm{mole})$ & Compound & $\Delta \mathrm{H}_{\text {form }}(\mathrm{kcal} / \mathrm{mole})$ \\
\hline $\mathrm{CH}_{3} \mathrm{CH}_{3}$ & -20 & ${ }^{\mathrm{a}} \mathrm{CH}_{3} \mathrm{NO}_{2}$ (aq) & -8 \\
\hline $\mathrm{CH}_{3} \mathrm{CH}_{2} \mathrm{OH}(\mathrm{aq})$ & -66 & $\mathrm{HCO}_{2} \mathrm{H}(\mathrm{aq})$ & -98 \\
\hline $\mathrm{CH}_{3} \mathrm{OH}(\mathrm{aq})$ & -59 & $\mathrm{NO}_{2} \cdot$ & 8 \\
\hline $\mathrm{CH}_{3} \mathrm{CHO}(\mathrm{aq})$ & -50 & $\mathrm{HNO}_{2}(\mathrm{aq})$ & -28 \\
\hline $\mathrm{CH}_{3} \mathrm{CH}_{2}$ & 26 & $\mathrm{HNO}_{3}(\mathrm{aq})$ & -49 \\
\hline${ }^{\mathrm{a}} \mathrm{CH}_{3}(\mathrm{O}) \mathrm{C}$ & -21 & NO & 22 \\
\hline${ }^{\mathrm{a}} \mathrm{CH}_{3} \mathrm{CH}_{2} \mathrm{OOH}$ & -35 & $\mathrm{H}_{2} \mathrm{O}$ & -68 \\
\hline${ }^{8} \mathrm{CH}_{3} \mathrm{CH}_{2} \mathrm{OO}$ & 23 & $\mathrm{CO}_{2}(\mathrm{aq})$ & -98 \\
\hline $\mathrm{CH}_{3} \cdot$ & 31 & $\mathrm{NH}_{2} \mathrm{OH}(\mathrm{aq})$ & -22 \\
\hline
\end{tabular}

approximated using other values ${ }^{1,2}$.

$\mathrm{R}$ denotes an organic group unaffecting the $\Delta \mathrm{H}$ for the shown reaction. The oxidation of organic compounds is usually initiated by the production of organic radicals generated by dissolved $\mathrm{NO}_{2} \cdot$ and $\mathrm{NO} \cdot$ in solution. For many types of organic compounds the attack by $\mathrm{NO}_{2} \cdot$ can be first order.

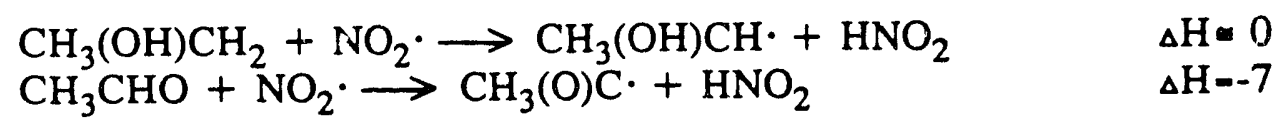

For aliphatic compounds high concentrations of $\mathrm{NO}_{2} \cdot$ and $\mathrm{NO} \cdot$ are needed.

$$
\begin{array}{ll}
\mathrm{RCH}_{3}+\mathrm{H}_{2} \mathrm{O}+3 \mathrm{NO}_{2} \cdot \longrightarrow \mathrm{RCH}_{2}+2 \mathrm{HNO}_{2}+\mathrm{HNO}_{3} & \Delta \mathrm{H} \propto-15 \\
\mathrm{RCH}_{3}+\mathrm{H}_{2} \mathrm{O}+2 \mathrm{NO}_{2} \cdot+\mathrm{NO} \cdot \longrightarrow \mathrm{RCH}_{2}+3 \mathrm{HNO}_{2} & \Delta \mathrm{H}-8
\end{array}
$$

A typical aliphatic carbon-hydrogen bond strength of $99 \mathrm{kcal} / \mathrm{mole}$ was used in the calculations ${ }^{2}$. Adding oxygen to the solution, by air sparging, can set up a radical propagating oxidation mechanism. Organic radicals quickly react with molecular oxygen to form a peroxic radical.

$$
\mathrm{RCH}_{2} \cdot+\mathrm{O}_{2} \rightarrow \mathrm{RCH}_{2} \mathrm{OO} \cdot \quad \Delta \mathrm{H}=-3
$$

The peroxic radical can easily abstract a hydrogen from even an aliphatic organic molecule since an oxygen-hydrogen bond is formed to break a carbon-hydrogen bond. This results in an organic hydroperoxide and another organic radical. Above $130-150^{\circ} \mathrm{C}$ the organic hydroperoxides decompose to release $\mathrm{H}_{2} \mathrm{O}$ or $\mathrm{CO}_{2}{ }^{1}$.

$$
\begin{array}{ll}
\mathrm{RCH}_{2} \mathrm{OO} \cdot+\mathrm{RCH}_{3} \longrightarrow \mathrm{RCH}_{2} \mathrm{OOH}+\mathrm{RCH}_{2} \cdot & \Delta \mathrm{H} \approx-12 \\
\mathrm{RCH}_{2} \mathrm{OOH} \rightarrow \mathrm{RCHO}+\mathrm{H}_{2} \mathrm{O} & \Delta \mathrm{H} \approx-83
\end{array}
$$


The organic radicals can also be oxidized by nitric and nitrous acids or nitrated by $\mathrm{NO}_{2}$.

$$
\begin{array}{ll}
\mathrm{RCH}_{2}+\mathrm{HNO}_{3} \longrightarrow \mathrm{RCH}_{2} \mathrm{OH}+\mathrm{NO}_{2} \cdot & \Delta \mathrm{H} \approx-35 \\
\mathrm{RCH}_{2}+\mathrm{HNO}_{2} \longrightarrow \mathrm{RCH}_{2} \mathrm{OH}+\mathrm{NO} \cdot & \Delta \mathrm{H} \approx-42 \\
\mathrm{RCH}_{2}+\mathrm{NO}_{2} \cdot \rightarrow \mathrm{RCH}_{2} \mathrm{NO}_{2} & \Delta \mathrm{H} \approx-52
\end{array}
$$

Oxidation of the carbon-carbon bond is also possible but slow probably due to steric factors.

$$
\mathrm{CH}_{3} \mathrm{CH}_{3}+\mathrm{NO}_{2} \cdot+\mathrm{H}_{2} \mathrm{O} \rightarrow 2 \mathrm{CH}_{3} \mathrm{OH}+\mathrm{NO} \cdot \quad \Delta \mathrm{H}--16
$$

\section{Methods and Materials}

Weight measurements were taken using a Sartorious (Handy) balance. All chemicals used were of at least Reagent grade quality meeting ACS specifications except for the cellulose (Whatman 40 ashless filter paper) and neoprene (glovebox glove made by Siebe North, Inc., Charleston SC). Gas samples were analyzed on a Varian 3400 GC using Molecular Sieve-13X and Chromosorb 106 columns.

The data collected was generated from two similar but different oxidation systems. The first used a peristaltic pump to circulate air through a closed system starting with (and continuing in order) a three liter reaction vessel containing a liter of reactant solution, an ice trap, a 26.6 liter polypropylene bottle, a $30 \mathrm{ml}$ gas sample vessel, and then re-enetereing the peristaltic pump. The system was connected to an inverted burette, in acidic solution, used to measure changes in the gas volume of the system. The total gas volume of the system was $29.0 \pm 0.2$ liters. The air entered the reaction solution through a three inch diameter medium glass frit plate generating very small bubbles in the solution. The air circulation rate for this system was maintained at 500 $\mathrm{ml} / \mathrm{minute}$. The all-glass three liter reaction vessel set in a heating mantle and had four ground glass openings which provided access for a thermometer, an air cooled condenser (air outlet), air sparge inlet, and sample introduction-holder port. Gas samples were taken at the beginning, end, and during the oxidation reaction. Carbon balance results gave a combined error of $\pm 3 \%$.

The second system was of a flow-through design. A peristaltic pump was used to push air through the reaction system. The incoming air was stripped of $\mathrm{CO}_{2}$ using Ascarite-II (Thomas Scientific). The air was delivered to the reaction vessel at $100 \mathrm{ml} / \mathrm{minute}$. The reaction vessel was the same as described above except that a smaller glass frit sparger was used. The gas stream leaving the reaction vessel was scrubbed of $\mathrm{NO}_{2} \cdot$ by a $0.5 \mathrm{M}$ sulfamic acid solution. The products of the $\mathrm{NO}_{2} \cdot$ reaction with the sulfamic acid was nitric acid (stays in solution) and $\mathrm{N}_{2}$ gas. The gas stream then entered approximately 100 grams of Ascarite-II in a polypropylene bottle. Weighing the bottle before and after the reaction determined the weight of $\mathrm{CO}_{2}$ produced from the oxidation. The gas stream then entered a column of Pd metal on a Kieselguhr support maintained above $140^{\circ} \mathrm{C}$. The $\mathrm{Pd} / \mathrm{Kieselguhr}$ catalyzes the air oxidation of any $\mathrm{CO}$ in the gas stream to $\mathrm{CO}_{2}$. The generated $\mathrm{CO}_{2}$ is then absorbed and weighed on a second bottle of AscariteII. Calibration of this system for the absorption of $\mathrm{CO}$ and $\mathrm{CO}_{2}$ was accomplished by adding a weighed amount of dried sodium oxalate to concentrated sulfuric or phosphoric acid. In the 
WSRC-MS-93-169

$\mathrm{Pg} 4$ of 8

absence of oxidizing compounds an equal molar amount of $\mathrm{CO}$ and $\mathrm{CO}_{2}$ is formed. Carbon balances from the calibration determined a combined accuracy of $\pm 2 \%$.

\section{Results and Discussion}

The onset of oxidation for the soluble organic compounds was about $120^{\circ} \mathrm{C}$. Gram quantities of organic material was oxidized per run. At $140^{\circ} \mathrm{C}$ the oxidation was complete in less than 15 minutes $\left(\mathrm{NO}_{2} \cdot\right.$ stopped being released from the solution). The results of the carbon balance studies are tabulated in Table 2. Complete oxidation, within experimental error, was obtained for the compounds listed (with the exception of tartaric acid) for at least one of the runs. Tartaric acid should also be completely oxidizable. The purpose for the oxidation of tartaric acid was to determine the fraction of $\mathrm{CO}$ released. The results show that a more highly oxidized compound, such as tartaric acid, releases a smaller fraction of $\mathrm{CO}$. The production of $\mathrm{CO}$ was very pronounced for TBP (tributylphosphate) and nitromethane. The result for nitromethane is not surprising since it should be quickly hydrolysed to formic acid in a strong mineral acid at these temperatures ${ }^{3}$.

$$
\begin{array}{ll}
\mathrm{CH}_{3} \mathrm{NO}_{2}+\mathrm{H}_{2} \mathrm{O}+\mathrm{H}_{3} \mathrm{PO}_{4} \rightarrow \mathrm{HCO}_{2} \mathrm{H}+\mathrm{H}_{2} \mathrm{NOH} \cdot \mathrm{H}_{3} \mathrm{PO}_{4} & \Delta \mathrm{H}-44 \\
\mathrm{H}_{2} \mathrm{NOH} \cdot \mathrm{H}_{3} \mathrm{PO}_{4}+\mathrm{HNO}_{2} \rightarrow \mathrm{N}_{2} \mathrm{O}+2 \mathrm{H}_{2} \mathrm{O}+\mathrm{H}_{3} \mathrm{PO}_{4} & \Delta \mathrm{H}=-66
\end{array}
$$

Dehydration of formic acid to $\mathrm{CO}$ and water is sightly endothermic $(4 \mathrm{kcal} / \mathrm{mole})^{2}$ but probably quick in $14.8 \mathrm{M} \mathrm{H}_{3} \mathrm{PO}_{4}$ which is a strong dehydrating agent. The strong dehydrating ability of the reaction solution is probably aiding in the decomposition of the organic oxidation products. Cellulose is rapidly carbonized at around $140^{\circ} \mathrm{C}$ to form carbon and water.

$$
\begin{aligned}
& \mathrm{RCH}(\mathrm{OH}) \mathrm{CO}_{2} \mathrm{H} \rightarrow \mathrm{H}_{2} \mathrm{O}+\mathrm{CO}+\mathrm{RCHO} \\
& \mathrm{C}_{6} \mathrm{H}_{10} \mathrm{O}_{5} \text { (cellulose) } \rightarrow 6 \mathrm{C}+5 \mathrm{H}_{2} \mathrm{O}
\end{aligned}
$$

The carbon formed is easily attacked by the nitric acid. It is possible that the relative production of $\mathrm{CO}$ and $\mathrm{CO}_{2}$ is determined by competing mechanisms; the $\mathrm{CO}$ by a dehydration mechanism and the $\mathrm{CO}_{2}$ produced by oxidation with $\mathrm{HNO}_{3}$ and $\mathrm{NO}_{2}$.

$$
\begin{array}{ll}
\mathrm{CH}_{3} \mathrm{CHO}+\mathrm{NO}_{2} \cdot \longrightarrow \mathrm{CH}_{3}(\mathrm{O}) \mathrm{C} \cdot+\mathrm{HNO}_{2} & \Delta \mathrm{H}--7 \\
\mathrm{CH}_{3}(\mathrm{O}) \mathrm{C} \cdot+\mathrm{HNO}_{3} \longrightarrow \mathrm{CH}_{3} \cdot+\mathrm{CO}_{2}+\mathrm{HNO}_{2} & \Delta \mathrm{H}-4
\end{array}
$$

The slightly endothermic $\Delta \mathrm{H}$ for this last reaction shows how dehydration to produce $\mathrm{CO}$ can compete with oxidation to produce $\mathrm{CO}_{2}$.

Carbon-nitrogen bonds are relatively weak $(\sim 75 \mathrm{kcal} / \mathrm{mole})^{1}$ so complete oxidation of EDTA (ethylene-diamine-tetraacetic acid) was not surprising. Oxidation of TBP was performed to test the ability to destroy nearly aliphatic compounds. Butanol, a hydrolysis product of TBP, resembles an aliphatic compound except for the alcohol group. The weakening of the adjacent carbon-hydrogen bonds by this lone oxygen seems to be sufficient to start the chain oxidation 
WSRC-MS-93-169

$\mathrm{Pg} 5$ of 8

Table 2. Carbon Balance for Oxidation of Various Organic Compounds in a $0.05-0.1 \mathrm{M} \mathrm{HNO}_{3} / 14.8 \mathrm{M} \mathrm{H}_{3} \mathrm{PO}_{4}$ Solution, $120-160^{\circ} \mathrm{C}$.

\begin{tabular}{|c|c|c|c|}
\hline Compound & $\begin{array}{l}\text { Co-catalyst } \\
\text { Metal (conc.) }\end{array}$ & $\begin{array}{c}\text { Percentage } \\
\text { Carbon Released } \\
\text { as } \mathrm{CO}_{2} \text { and } \mathrm{CO}\end{array}$ & $\begin{array}{l}\text { Percentage } \mathrm{CO} \\
\text { of } \mathrm{CO}_{2} \text { and } \mathrm{CO}\end{array}$ \\
\hline $\begin{array}{l}\text { cellulose } \\
\text { EDTA } \\
" ~ \\
" \\
\text { TBP } \\
" \\
\text { nitromethane } \\
" \\
\text { tartaric acid } \\
\text { neoprene }\end{array}$ & $\begin{array}{c}\text { none } \\
\mathrm{Pd}(0.0012 \mathrm{M}) \\
\mathrm{Rh}(0.003 \mathrm{M}) \\
\text { none } \\
\mathrm{Pd}(0.0012 \mathrm{M}) \\
\mathrm{Rh}(0.003 \mathrm{M}) \\
\text { none } \\
\mathrm{Pd}(0.0012 \mathrm{M}) \\
\text { none } \\
\mathrm{Pd}(0.0012 \mathrm{M}) \\
\text { none } \\
\mathrm{Pd}(0.001)\end{array}$ & $\begin{array}{c}98 \pm 2^{a} \\
99 \pm 2 \\
97 \pm 3^{a} \\
99 \pm 2 \\
>91 \pm 2 \\
>84 \pm 3^{a} \\
103 \pm 3^{a} \\
- \\
101 \pm 2 \\
- \\
>96 \pm 2 \\
101 \pm 10\end{array}$ & $\begin{array}{l}20 \pm 1 \\
0.9 \pm 1 \\
6.3 \pm 1.5 \\
25 \pm 1 \\
0.9 \pm 1 \\
19 \pm 1.5 \\
43 \pm 1 \mathrm{~b} \\
1.3 \pm 1 \\
60 \pm 1 \\
2.3 \pm 1 \\
15 \pm 1 \\
<17\end{array}$ \\
\hline
\end{tabular}

a GC analysis observed no $\mathrm{H}_{2}$, methane, or ethane.

b Determined from butanol (a hydrolysis product of TBP)

process. Oxidation of compounds of this type have been said to act like a candle that has been lit on one end ${ }^{1}$. The carbon atoms are oxidized in order down the chain.

The surface oxidation of neoprene (poly [2-chloro-1,3-butadiene]) was found to be even, allowing measurement of the surface area and weight loss during its destruction. The oxidation rate at varying temperatures has been measured for this compound, Figure 1. The activation energy, $E_{a}$, was determined to be $22.9 \mathrm{kcal} /$ mole with a frequency factor, $A$, of $7.68 \mathrm{E} 11 \mathrm{~s}^{-1}$. The release of chloride during the oxidation had no observable effect at the low concentration, up to $0.1 \mathrm{M}$, formed by the destruction of the neoprene. Oxidation of neoprene is relatively rapid due to carbon-carbon double bond weakening of carbon-hydrogen bonds in $\alpha$ positions relative to the double bond ${ }^{1}$.

The oxidation of aliphatic compounds such as polyethylene, PVC (polyvinylchloride), and $\mathrm{n}$-dodecane was found to be unmeasureably slow in this reaction solution below $180^{\circ} \mathrm{C}$. In an air sparged system the concentration of $\mathrm{NO} \cdot$ and $\mathrm{NO}_{2} \cdot$ should be too low for reactions (1) and (2) to have any appreciable effect. In near $0.1 \mathrm{M} \mathrm{HNO}_{3}$ solution reactions (3), (4), and (5) would be hampered by destruction of the organic radicals by reactions (6), (7), and (8). It should be possible though under the right reaction conditions to oxidize aliphatic compounds by reactions $(3),(4)$, and (5) or (6), (7), and (8) in this temperature range ${ }^{1}$.

Two platinum group metals were studied as co-catalysts, palladium and rhodium. Palladium performed better in reducing the percentage of organic carbon released from solution 
as $\mathrm{CO}$. The palladium metal formed during the oxidation of $\mathrm{CO}$ is reoxidized back to $\mathrm{Pd}^{+2}$ by nitric acid.

$$
\begin{aligned}
& \mathrm{CO}+\mathrm{Pd}^{+2}+\mathrm{H}_{2} \mathrm{O} \rightarrow \mathrm{CO}_{2}+\mathrm{Pd}+2 \mathrm{H}^{+} \\
& \mathrm{Pd}+2 \mathrm{HNO}_{3} \longrightarrow \mathrm{Pd}^{+2}+\mathrm{H}_{2} \mathrm{O}+2 \mathrm{NO}_{2}^{-}
\end{aligned}
$$

Unlike palladium, rhodium formed a significant amount of $\mathrm{N}_{2} \mathrm{O}$ when used as a co-catalyst. Rhodium catalyzes the NO- oxidation of $\mathrm{CO}$ to prociuce $\mathrm{CO}_{2}$ and $\mathrm{N}_{2} \mathrm{O}^{4}$. Even though the extent to which palladium is aiding in oxidation of the organic materials in solution is unknown, palladium is known to be an effective catalyst for oxidation of many types of organic compounds ${ }^{5}$.

During some runs when an air sparge rate of $500 \mathrm{ml} /$ minute was used, the solution temperature had to be raised to near $150^{\circ} \mathrm{C}$ to complete the oxidation. This is probably due to the formation of hydroperoxide compounds which decompose in the $130-150^{\circ} \mathrm{C}$ range $e^{1}$. The extent to which the oxygen is interacting with the organic radicals is unknown. Oxygen could also enter as an oxidant by oxidizing dissolved $\mathrm{NO} \cdot$ to $\mathrm{NO}_{2}$. Even though the selfdecomposition of organic hydroperoxides have a high activation energy ${ }^{1}$, the concentration of these compounds are self limiting

$$
\mathrm{RCH}_{2} \mathrm{OOH}+\mathrm{R}^{\prime} \mathrm{CH}_{2} \mathrm{OOH} \rightarrow \mathrm{RCHO}+\mathrm{R}^{\prime} \mathrm{CHO}+2 \mathrm{H}_{2} \mathrm{O} \quad \Delta \mathrm{H} \approx-166
$$

\section{Conclusions}

Complete oxidation of many types of organic compounds is possible in a $0.1 \mathrm{M} \mathrm{HNO}_{3} / 14.8 \mathrm{M}$ $\mathrm{H}_{3} \mathrm{PO}_{4}$ solution with air sparging. Oxidation of aliphatic compounds will require different and maybe more extreme conditions (i.e, pressurization and high nitric acid concentrations). Trace amounts of palladium should be capable of minimizing the production of $\mathrm{CO}$ to near $1 \%$ of the released carbon gases. Use of palladium should also minimize the production of $\mathrm{N}_{2} \mathrm{O}$ which can not easily be reoxidized to $\mathrm{HNO}_{3}$.

The released $\mathrm{HNO}_{3}, \mathrm{NO}$, and $\mathrm{NO}_{2}$ can be reoxidized in a standard air driven acid recovery system providing a cheaf source of oxidant. There should be no ash produced from the process making this process more environmentally contained. There are existing resins that can be used to absorb hazardous metals such as mercury, silver, lead, and cadmium that work well in phosphate solutions ${ }^{6}$. The reaction conditions were relatively mild, ambient pressure and $<180^{\circ} \mathrm{C}$, making the process potentially easy and cheap to implement. Phosporic acid, $\mathrm{H}_{3} \mathrm{PO}_{4}$, and its solutions only mildly attack common stainless-steels (such as 304-L), especially at room temperature ${ }^{7}$. This would make handling and containing process solutions in plumbing and tanks safe and inexpensive.

\section{Acknowledgements}

This work was supported by the Department of Energy under Contract No. DE-AC0988SR19035. I would like to acknowledge David T. Hobbs of SRTC/WSRC for his gas sample alysis support. 


\section{Notation}

$\Delta \mathrm{H}$ - standard heat (enthalpy) of reaction, $\Delta \mathrm{H}^{\circ}{ }_{298}$

$\mathrm{R}$ - an organic group unaffecting the $\Delta \mathrm{H}$ for the shown reaction.

neoprene - poly (2-chloro-1,3-butadiene)

EDTA - ethylenediaminetetraacetic acid

TBP - tributylphosphate

tartaric acid - 2,3-dihydroxybutanedioic acid

Acsarite-II - solid $\mathrm{NaOH}$ on a solid support (for $\mathrm{CO}_{2}$ absorption).

Kieselguhr - diatomaceous earth (silica from the skeletons of diatoms).

\section{References}

1 Seminov, N.N., Some Problems in Chemical Kinetics and Reactivity, Princeton Univ. Press, vol. 1 and 2, 1958.

2 Dickerson, R.E., Molecular Thermodynamics, the Benjamin/Cummings Publ. Co., 1969.

3 Fuson, R.C., Advanced Organic Chemistry, John Wiley and Sons, Inc., 1950, p. 507.

4 Dickson, R.S., Organometallic Chemistry of Rhodium and Iridium, Academic Press, Inc., 1983, p. 7.

5 Maitlis, P.M., The Organic Chemistry of Palladium, Academic Press, Inc., 1971.

6 Osreen, A.B. and Bibler, J.P., Treatment of Radioactive Laboratory Waste for Mercury Removal, Water, Air, and Soil Pollution, 56, 63-74 (1991).

7 Schweitzer, P.A. (editor), Corrosion Resistance Tatles, 3rd Edition, Marcel Dekker, Inc., 1991. 


\section{Figures}

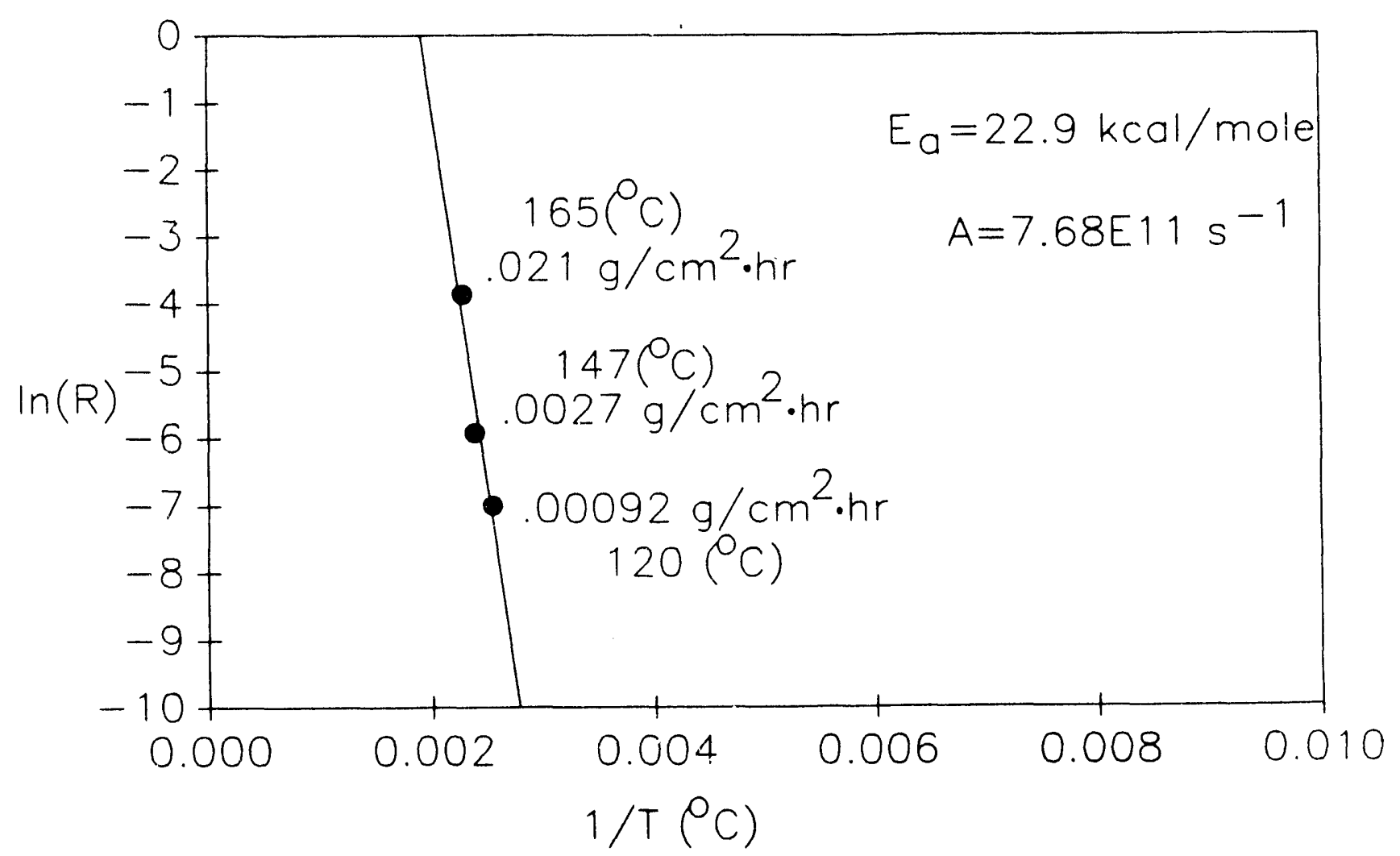

Figure 1. Oxidation Rate, $\mathrm{R}$, for Neoprene in $0.1 \mathrm{M} \mathrm{HNO} / 14.8 \mathrm{M} \mathrm{H}_{3} \mathrm{PO}_{4}$ Solution at Varying Temperature. 

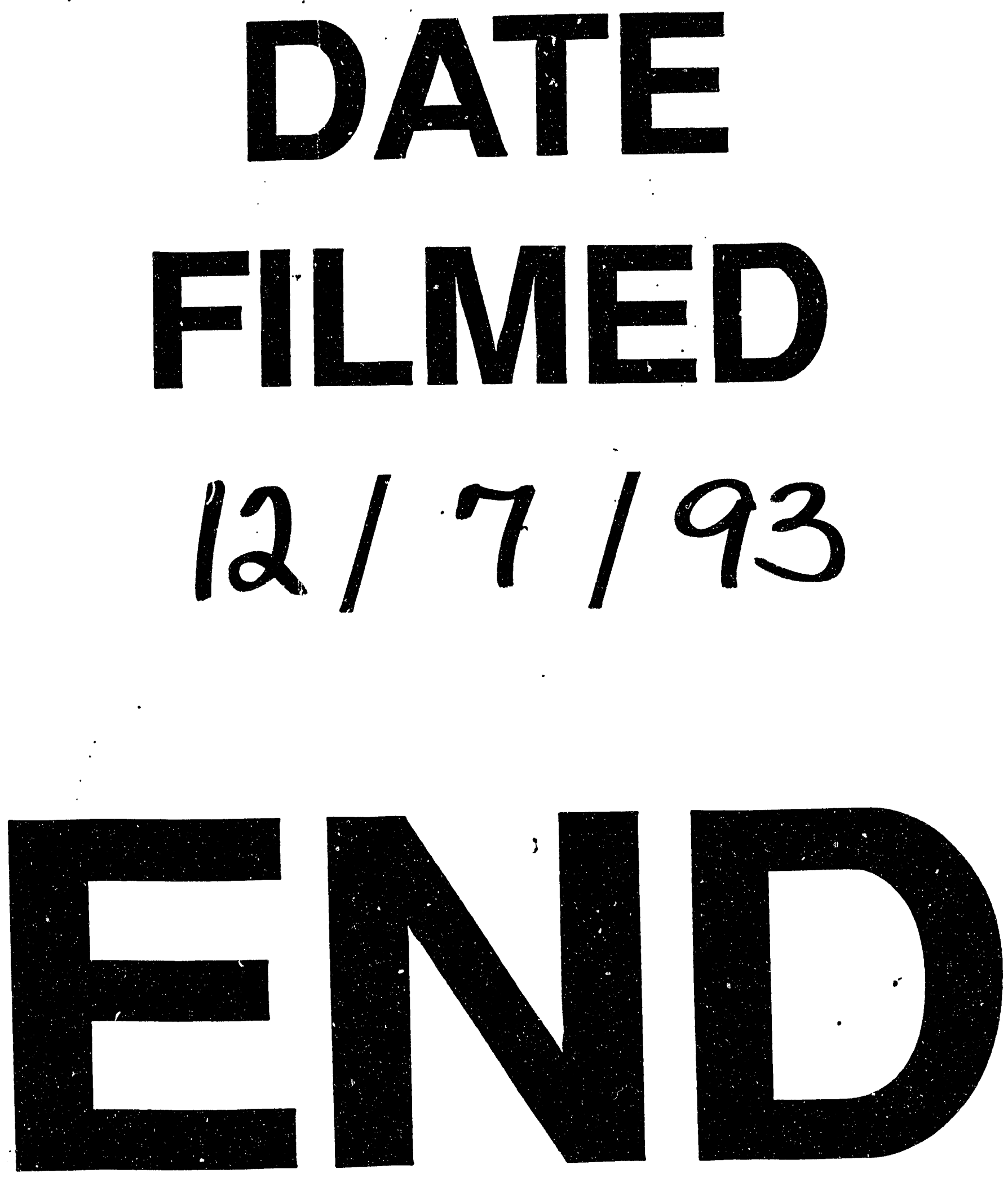